\title{
REVOLUSI YAYASAN SOSIAL DAN KEMANUSIAAN TERINTEGRASI BAGI ANAK JALANAN DAN YATIM PIATU DALAM NILAI-NILAI ISLAM
}

\author{
Imamul Arifin, Andika Adinul Yahya, Muhammad Thoriq Azzam \\ Politeknik Elektronika Negeri Surabaya \\ Jl.Raya ITS - Kampus PENS Sukolilo Surabaya 60111 \\ E-Mail: yahya0029.97@gmail.com
}

\begin{abstract}
The Revolution of Human Resources (SDA) and Mental Nation is indeed important today to sustain the progress of the nation. But before that, it must be realized about the lack of attention to education for people who are not addressed, for example street children and orphans in need. All elements of the nation should be realize of the deficiency or something that needs to be improved from this. The government, educational institutions and humanitarian social bodies that form the nation's generation are very important for this. But here, it is emphasized for the Social Foundation and humanity to be more able to pay attention to their future needs for the better, because this institution is a suitable place for them to get quality education, character, and morals that are in accordance with Islamic values, where the aim is to provide equitable justice for the people's and make a better national life.
\end{abstract}

Keywords: Revolution, social and humanitarian foundation, Islam

\begin{abstract}
Abstrak: Revolusi Sumber Daya Manusia (SDA) dan Mental bangsa memanglah penting di era sekarang untuk menopang kemajuan bangsa. Namun sebelumnya, haruslah disadari tentang kurangnya perhatian terhadap pendidikan bagi masyarakat yang tidak diperhatikan, contohnya anak jalanan dan anak yatim piatu yang membutuhkan. Harusnya semua elemen bangsa menyadari tentang kekurangan atau sesuatu hal yang perlu diperbaiki dari ini. Pemerintah, instansi/lembaga pendidikan dan badan sosial kemanusiaan pembentuk generasi bangsa sangatlah berperan penting. Namun disini, ditekankan bagi Yayasan Sosial dan kemanusiaanlah untuk lebih bisa memperhatikan kebutuhan masa depan mereka menjadi lebih baik, karena instansi inilah sebagai tempat yang cocok bagi mereka untuk mendapat pendidikan, karakter, dan moral yang berkualitas dan sesuai dengan nilai-nilai keislaman, yang mana tujuannya adalah memberikan keadilan merata bagi masyarakat dan memajukan kehidupan bangsa yang lebih baik.
\end{abstract}

Kata kunci: revolusi, yayasan sosiaL, kemanusiaan, islam.

\section{PENDAHULUAN}

Pemerintah dan masyarakat pasti membutuhkan organisasi atau badan di bidang sosial. Disini keberadaan sebuah yayasan sebagai organisai dan badan hukum yang bergerak dilingkup sosial sangatlah penting, hal ini juga terkait didalam UUD RI tahun 1945, pasal 27, pasal 31 dan pasal 34 yang mengatur tentang kebutuhan-kebutuhan tersebut. Yayasan harus menjalankan tugas sesuai dengan visi dan misinya dan dilandasi dengan dasar hukum dan ikhtikad baik. Didirikannya yayasan yang bersifat sosial, kemanusiaan, dan keagamaan tujuannya tidaklah untuk mencari keuntungan pribadi, melainkan sebagai media untuk membantu masyarakat di lingkup 
tersebut.[1][2]

Namun yang perlu dibenahi disini yaitu tentang pengintegrasian yayasan-yayasan di seluruh Indonesia, berdasarkan riset pencarian data dari Direktorat Jenderal AdministrasiHukumUmum Kementerian Hukum Dan Hak Asasi Manusia Republik Indonesia, jumlah yayasan di Indonesia mencapai angka ribuan, baik dari perseorangan atau perusahaan yang tercatat, bisa terjadi kemungkinan juga bagi yayasan di luar sana yang belum didata oleh pemerintah. Melihat sistem pendirian yayasan di Indonesia sekarang masih perlu dievaluasi. Terlalu banyak berdirinya yayasan yang kurang efektif membuat manfaat dari yayasan tersebut timbul kekurangannya, yaitu:

1. Banyaknya yayasan yang telah berdiri hanya seumur kucuran dari dana bantuan yang ada.

2. Resiko keuntungan pribadi atau komersil kepada satu pihak atau pihak lain dengan alibi fungsi yayasan ini sendiri, dan hal ini diakibatkan dari kebebasan mendirikan yayasan yang telah di atur di UU Yayasan.

3. Kurang efektifnya dana bantuan yang diberikan oleh negara, masyarakat, atau pihak lain akibat banyaknya yayasan yang akan menerimanya.[3]

4. Terlalu kecilnya lingkup pengaruh yayasan, karena banyak yayasan yang hanya bergerak di aspek sosial tertentu (contoh : yayasan anak yatim/piatu, yayasan anak jalanan, yayasan anak miskin,dll). Padahal lingkup aspek tersebut masih mencakup visi misi yayasan yang kurang lebih sama dan bisa digabung.

5. Terlalu banyaknya yayasan yang kurang efektif, menunjukkan kualitas masalah sosial di negara ini cukup memprihatinkan dan penanganannya kurang maksimal, dan otomatis dampak banyaknya yayasan bisa menimbulkan resiko-resiko permasalahan baru di masa yang akan datang.[4]
Dari pemaparan diatas disebutkan tentang kekurangan dan resiko munculnya kemudharatan daripada manfaatnya, akibat semakin banyak berdirinya yayasan yang tidak terkontrol, khususnya yayasan anak jalanan dan anak yatim/ piatu. Al Quran, Surah Al-Isra ayat 34

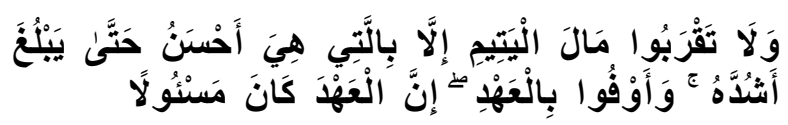

"Dan janganlah kamu mendekati harta anak yatim, kecuali dengan cara yang lebih baik (bermanfaat) sampai ia dewasa dan penuhilah janji; sesungguhnya janji itu pasti diminta pertanggungan jawabnya." Surah An nisa' ayat 10

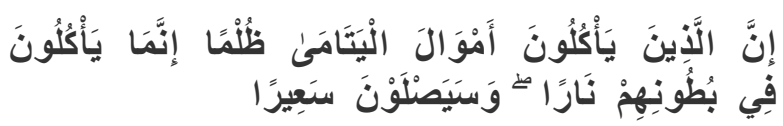

"Sesungguhnya orang-orang yang memakan harta anak yatim secara zalim, sebenarnya mereka itu menelan api sepenuh perutnya dan mereka akan masuk ke dalam api yang menyala-nyala (neraka)."

Surah Al maidah ayat 1 :

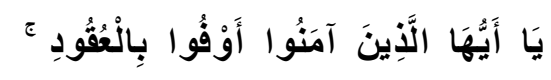

"Hai orang-orang yang beriman, penuhilah aqad-aqad itu..."

Penafsiran dari penggalan Surah Al Maidah ayat 1 ini yaitu, bagi orangorang yang beriman kepada Allah SWT untuk menyempurnakan aqad atau janjijanjinya yang kuat baik kepada Allah SWT dan kepada manusia lainnya. Dalam penjelasan ayat di atas, disinggung berdasarkan ayat-ayat al quran dari resiko - resiko yang membuat munculnya masalah baru, akibat banyak berdirinya yayasan - yayasan baru, tertuju bagi mereka yang berniat menyimpang dari jalan Allah dengan memakan harta anak yatim melalui yayasan. Pada poin $a, b$, 
dan e disinggung jelas dalam ayat-ayat al quran diatas tentang dosa dan hukuman besar dari Allah SWT bagi mereka yang memakan harta anak yatim dan anjuran bagi mereka untuk menyempurnakan semua aqad (janji) ketika seseorang berniat mendirikan suatu yayasan bagi anak jalanan dan anak yatim/piatu. Dan ayat-ayat al quran seperti diatas haruslah menjadi landasan bagi mereka yang berniat mendirikan yayasan -yayasan nantinya. Di sini anak jalanan dan anak yatim/piatu akan dijelaskan secara bersama, karena mereka adalah anak - anak dengan status sosial yang sama untuk diperhatikan.[5]

Makna Revolusi adalah perubahan yang cukup mendasar dalam suatu bidang. Sistem dan peraturan perundangundangan pendirian yayasan lah yang harus dibenahi disini. Sedangkan kata Integrasi adalah pembauran hingga menjadi kesatuan yang utuh atau bulat. Pengintegrasian yayasan yang akan dijelaskan ini, yaitu tentang yayasan bagi anak jalanan dan anak yatim/ piatu, dan tidak menutup kemungkinan untuk semua yayasan di semua lingkup sosial juga nantinya. Lingkup kedua hal yayasan ini memiliki tujuan dan visi misi yang kurang lebih sama. Anak jalanan dan anak yatim/piatu adalah anakanak yang memiliki nasib kedepannya yang hampir sama,bagaimana kualitas keberlangsungan hidup mereka?, bagaimana status sosial mereka nanti?, bagaiamana kualitas pendidikan formal, informal, akhlak dan moral mereka?, karakter apa yang terbentuk saat mereka dewasa nanti jika mereka kurang diperhatikan?, dan seterusnya. Dari data Kementerian Sosial (2018) mengklaim jumlah anak jalanan di Indonesia setiap tahun terus mengalami penurunan, saat ini masih tersisa 16 ribu anak jalanan di 35 provinsi di Indonesia. Dari 23,6 ribu anak jalanan pada 2017 menyusut menjadi
16 ribu per November 2018, Tentunya angka tersebut masih terbilang cukup tinggi. Dari sisi anak yatim/piatu, mereka termasuk yang masih memiliki kerabat/ saudara atau yang tinggal di panti asuhan. Menurut data Kemensos jumlahnya anak yatim/piatu mencapai 4,5 juta 10 dan pada jumlah anak yang tinggal di panti asuhan ada sebanyak 500 ribu hingga 600 ribu jiwa dan jumlah panti asuhan di seluruh Indonesia sekitar 7.000 unit. $11 \mathrm{Hal}$ ini menjadikan kita lebih memahami tentang penanganan mereka yang lebih baik.[6]

Persoalan anak jalanan dan anak yatim/piatu itu tergantung pada situasi dan kondisi mereka dan tidak pada status sosial mereka. Sehingga sangat penting partisipasi dan hubungan dengan lembaga-lembaga atau individu-individu yang konsen terhadap persoalanini. Faktor pengukuran keberhasilan dari solusi ini bukanlah seberapa banyak berdirinya yayasan jalanan dan anak yatim/piatu, melainkan seberapa maksimal pelayanan sosial yang diberikan ke mereka dengan lebih terintegrasinya sistem yayasan yang terarah. Maka dengan itu sistem pendirian yayasan di Indonesia perlulah di evaluasi lagi sesuai visi misi, kebutuhan dan manfaat yang lebih banyak dan berguna untuk mengatasi persoalan sekarang dan juga resiko persoalan jangka panjang nanti bagi masyarakat dan kesejahteraan bangsa.Tujuan dari pemaparan dalam penelitian ini adalah: Memahami peranan pemerintah, lembaga,dan khususnya yayasan yang bergerak di lingkup sosial, merevolusi sistem yayasan khususnya anak jalanan dan anak yatim/piatu yang terintegrasi dan maksimal, meningkatkan taraf kehidupan bagi anak jalanan dan anak yatim piatu dari segi Sumber Daya Manusia (SDM) dan Mental. Selanjutnya diharapkan penelitian ini dapat menjadi masukan dalam peran pemerintah dan yayasan-yayasan, dan sebagai bahan pertimbangan pembaharuan bagi 
revolusi sistem berdirinya yayasanyayasan nanti di lingkup yang lebih luas pada umumnya.[7][8]

\section{KERANGKA TEORI}

Setiap anak memiliki hak mereka masing-masing, dijelaskan lengkap di Undang-Undang Republik Indonesia Nomor 35 Tahun 2014 Tentang Perubahan Atas Undang-Undang Nomor 23 Tahun 2002 Tentang Perlindungan Anak. Anak jalanan dan anak yatim/piatu juga memiliki hak untuk hidup, Hak atas Pendidikan, Hak atas Makanan, Hak atas Kesehatan, Hak Atas Air, Hak untuk Identitas, Hak untuk Kebebasan, Hak atas Perlindungan, dan seterusnya. Namun biasanya mereka anak jalanan atau anak yatim piatu yang tidak diperhatikan biasanya akan mengalami kekerasan, baik fisik, seksual, psikis, dan ekonomi. Tercatat kasus kekerasan pada anak tahun 2016-2019 terus meningkat, bahkan di awal tahun 2020 ini, Komisi Perlindungan Anak Indonesia (KPAI) masih mencatat kasus seksual pada anak masih mencuat. Berdasarkan pada Undang-Undang Republik Indonesia Nomor 39 tahun 1999 tentang Hak Asasi Manusia yang tercantum pada poin ke sepuluh yaitu tentang hak anak menjelaskan bahwa setiap anak berhak untuk mendapatkan perlindungan hukum dari segala bentuk kekerasan fisik atau mentalpenelantaran, perlakuan buruk, dan pelecehan seksual selama dalam pengasuhan orang tua atau walinya, atau pihak lain manapun yang bertanggung jawab atas pengasuhan anak tersebut. [9]

Dari perspektif islam tentang anak jalanan tentunya tidak terlepas dari dalildalil al-quran sebagai landasannya. Tidak didapat sebuah ayat yang benar-benar membahas tentang anak jalanan. Anak jalanan identik dengan anak-anak yang menjadi pengamen, pengemis, tidak punya tempat tinggal, dan miskin yang menggantungkan hidupnya dijalanan.
Anak jalanan sendiri biasanya berawal dari keluarga yang kurang mampu, dan mereka biasanya akan memutuskan sekolahnya karena harus fokus dengan masalah ekonominya.

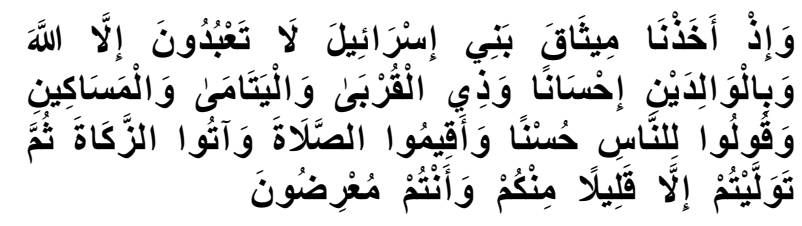

Pada surah Al-Baqoroh ayat 83, disebutkan berbuat baiklah kepada ibu bapak, kaum kerabat, anak-anak yatim, dan orang-orang miskin. Sebagian dari anak jalanan itu misalnya seorang yatim dan miskin maka tentunya ada anjuran untuk menyantuninya. Namun pada ayat ini tentunya kita menemukan indikasi yang jelas bahwa anak-anak yatim dan miskin itu tidak semuanya anak jalanan seperti yang ada pada saat sekarang ini, yang lebih cocoknya, disebut anak-anak yang meminta-minta. Orang tuanya masih hidup kedua-duanya dan masih kuat tentunya untuk menghidupi anak jalanan ini adalah tugas orang tuanya dan agama tidak membenarkan orang tua menelantarkan anaknya.

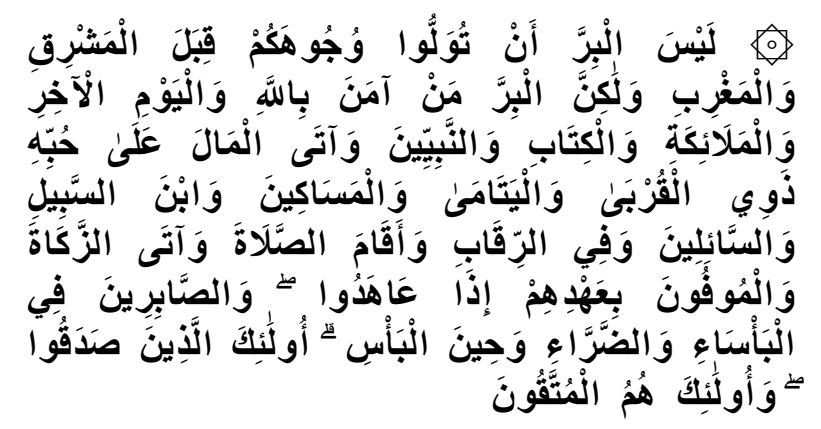

Pada surah Al Baqarah Ayat 177, disebutkan bahwa kebajikan itu ialah beriman kepada Allah, hari kemudian, malaikat-malaikat, kitab-kitab, nabinabi dan memberikan harta yang dicintainya kepada kerabatnya, anakanak yatim, orang-orang miskin, musafir (yang memerlukan pertolongan) dan orang-orang yang meminta-minta; 
dan (memerdekakan) hamba sahaya, mendirikan salat, dan menunaikan zakat; dan orang-orang yang menepati janjinya apabila ia berjanji, dan orang-orang yang sabar dalam kesempitan, penderitaan dan dalam peperangan. Mereka itulah orangorang yang benar (imannya); dan mereka itulah orang-orang yang bertakwa. Dapat kita pahami bahwa anak jalanan tergolong orang yang suka meminta-minta dijalanan dan menurut ayat ini dianjurkan untuk menyantuninya.

Dari sisi anak yatim piatu. Anak yatim adalah seseorang yang kehilangan orang tuanya sebelum mencapai usia dewasa. Menanggung anak yatim berarti mengurusi segala keperluan hidup, mengasuh, mendidik, dan menyantuni. Anak yatim piatu ini biasanya akan ditampung oleh panti asuhan atau ada juga yang diluar panti asuhan, sesuai dengan kondisi mereka masing-masing. Karena ditinggal oleh orang tuanya biasanya mereka akan mengalami kesusahan perekonomian dan hanya bisa menggantungkan nasibnya di panti asuhan atau kerabat dari keluarganya, yang dalam tanda kutip 'menumpang asuh'. Dan kebanyakan kasusnya, mereka akan dititipkan di panti asuhan. Sama halnya dengan anak jalanan, dan di panti asuhan pun mereka kurang bisa mendapatkan pendidikan formal atau softskill yang baik untuk masa depannya. Sehingga membuat mindset mereka hanya bisa mengikuti arus karena sesuai dengan kondisi ekonomi yang mereka dapati. Dalam Islam, Islam sangat memuliakan anak yatim. Bahkan tercatat ada 22 ayat tentang anak yatim dalam Alquran. Kita dilarang keras berbuat aniaya terhadap anak yatim. Sebaliknya, kita diperintah untuk senantiasa berbuat baik kepada mereka, seperti memberi makanan, menyantuni atau menjadi orang tua asuh bagi mereka. [4][10]

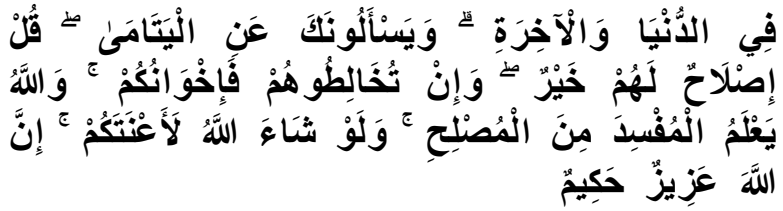

Tentang dunia dan akhirat. Dan mereka bertanya kepadamu tentang anak yatim, katakalah: "Mengurus urusan mereka secara patut adalah baik, dan jika kamu bergaul dengan mereka, maka mereka adalah saudaramu; dan Allah mengetahui siapa yang membuat kerusakan dari yang mengadakan perbaikan. Dan jikalau Allah menghendaki, niscaya Dia dapat mendatangkan kesulitan kepadamu. Sesungguhnya Allah Maha Perkasa lagi Maha Bijaksana.

Dalam sebuah hadits Ibnu Majah: «Sebaik-baik rumah di kalangan kaum Muslimin adalah rumah yang terdapat anak yatim yang diperlakukan dengan baik. Dan sejelek-jelek rumah di kalangan kaum Muslimin adalah rumah yang terdapat anak yatim dan dia diperlakukan dengan buruk.» (HR. Ibnu Majah).

Beberapa hadits Nabi SAW mengungkapkan keutamaan menyantuni anakyatim.SalahsatunyaketikaRasulullah SAW menjamin bahwa orang yang menyantuni anak yatim akan bersamanya nanti di surga. "Aku dan orang yang menanggung anak yatim (kedudukannya) di surga seperti ini», kemudian Beliau mengisyaratkan jari telunjuk dan jari tengah dan merenggangkan keduanya.» (HR Bukhari). Namun bagaimana jika anak yatim tersebut adalah non-Muslim, apakah kita tetap dianjurkan untuk menyantuninya? Bagaimana hukum menyantuni anak yatim non-Muslim dalam Islam? Menyantuni anak yatim nonMuslim dalam Islam diperbolehkan. Kita tidak dilarang untuk berbuat kepada nonMuslim. Dalam surah Almumtahanah ayat 8 , Allah berfirman; 


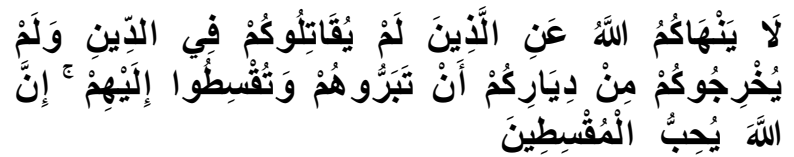

Ayat ini berisi penegasan dari Allah bahwa kita tidak dilarang untuk berbuat baik kepada non-Muslim dan berbuat adil kepada mereka selama mereka tidak terang-terangan memusuhi kita. Bahkan secara khusus Allah memerintahkan kepada kita untuk senantiasa berbuat baik dengan cara memberi makanan kepada orang-orang miskin, anak yatim dan tawanan perang. Meskipun orang-orang miskin, anak yatim dan tawanan perang tersebut adalah non-Muslim, namun kita tetap diperintah untuk memberi makanan kepada mereka. [11]

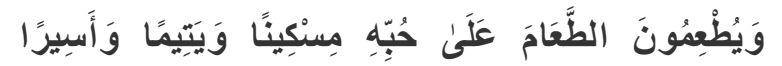

"Dan mereka memberikan makanan yang disukainya kepada orang miskin, anak yatim dan orang yang ditawan."

Disini peran sebuah Yayasan bagi mereka yang memberikan tempat untuk meningkatan Sumber Daya Manusia (SDM) dan Revolusi Mental bagi mereka. Revolusi mental ini tentang mengubah mindset mereka yang pasrah akan status sosialnya, menggantungkan hidup hanya dengan sikon ekonomi mereka yang membuat mereka tidak bisa leluasa mendapatkan pendidikan formal atau informal yang baik, berkarya ataupun memberi dampak yang bermanfaat bagi masyarakat bahkan negara.

\section{METODE PENELITIAN}

Metode penelitian yang digunakan adalah metode studi kasus dan kualitatif yaitu studi kasus dilakukan dengan pemeriksaan longitudinal yang mendalam terhadap suatu keadaan atau kejadian yang disebut sebagai kasus dengan menggunakan cara-cara yang sistematis dalam melakukan pengamatan, pengumpulan data, analisis informasi, dan pelaporan hasilnya. Dan kualitatif yaitu berangkat dari data yang diperoleh, memanfaatkan teori yang ada sebagai bahan penjelas. Sebagai hasilnya, akan diperoleh pemahaman yang mendalam tentang mengapa sesuatu terjadi dan dapat menjadi dasar bagi riset selanjutnya. Studi kasus dapat digunakan untuk menghasilkan dan menguji hipotesis. Teknik pengumpulan data dengan menggunakan teknik studi data, yaitu dengan meneliti berbagai macam sumber data yang berguna untuk bahan analisis. Metode analisis data yang digunakan yaitu teknik analisis data kualitatif dengan dilakukan analisis secara komprehensif dari awal sampai dengan akhir.[12]

\section{HASIL DAN PEMBAHASAN Revolusi Sistem Yayasan}

Aturan yang dijadikan rujukan untuk pendirian yayasan adalah UndangUndang Nomor Tahun 2001 Tentang Yayasan, sebagaimana diubah oleh Undang-Undang Republik Indonesia Nomor 28 Tahun 2004 (“Undang-Undang Yayasan"). Hal-hal tentang peraturan dan persyaratan didalamnya mungkin sudah baik, tetapi yang perlu dibenahi yaitu tentang pembatasan pendirian yayasan. Pembatasan ini dilakukan disesuaikan dengan kebutuhan dan tinjauan sasaran yang tepat dan efisien. Metode pendirian yayasan ini menggunakan sistem Demand and Supply. Demand yang dimaksud yaitu pendirian yayasan berdasarkan permintaan sesuai kebutuhan dari masalah yang ada, disini calon pendiri yayasan berkolaborasi dengan Pemda Provinsi setempat. Pemda Provinsi sebelumnya juga telah melakukan riset diwilayahnya tentang jumlah anak jalanan yang terlantar dan anak yatim/ piatu yang membutuhkan. Sedangkan Supply yaitu pendirian yayasan dilakukan oleh calon pendiri dengan melihat sikon yang telah diketahui dari data 
Pemda Provinsi setempat, lalu diberinya penawaran sesuai kebutuhan masalah kepada Pemda Provinsi untuk ijin mendirikan yayasan. [13] Disini peran pemerintah pusat untuk membenahi Peraturan Perundang-undangan Tentang Pendirian Yayasan dan partisipasi Pemda Provinsi setempat untuk menentukan perlu berdirinya yayasan atau tidak sesuai dengan data, kebutuhan dan kesejahteraan masyarakatnya yang efisien dan maksimal.[14]

Dan di sini revolusi yang harus dilakukan yaitu tentang yayasan anak jalanan dengan yayasan anak yatim piatu menjadi satu kesatuan. Karena mereka itu sama, yaitu anak-anak yang perlu diperhatikan. Tanpa membedakan visi misi yayasan dan status sosial mereka, alangkah baiknya mereka ditampung di satu yayasan yang sama dengan visi misi dantujuan yayasanyangmerata.Jikahalini dilakukan, maka membuat fungsi yayasan itu sendiri menjadi efisien dan maksimal, juga akan meminimalisir banyaknya yayasan yang akan berdiri. Beda halnya dengan yayasan yang bergerak di lingkup anak-anak berkebutuhan khusus, seperti yayasan anak penyandang distabilitas ,difabel dan anak cacat. Karena lingkup dan penanganannya mereka berbeda. Bagi seseorang yang ingin memberikan bantuannya tidaklah harus dengan mendirikan yayasan, mereka juga bisa ikut kedalam kepengurusan yayasan yang sudah ada, dengan revolusi sistem ini, maka yayasan akan tumbuh pesat. Dari segi dana dan bantuan baik dari pemerintah, masyarakat dan pihak lain bisa menjadi lebih. Agar pemahaman lebih bisa dipahami lagi, disini peneliti memiliki hipotesis tentang pendirian sebuah yayasan yang bernama "Anod Foundation". Yayasan ini nantinya diharapakan akan menjadi percontohan untuk sistem dan revolusi terhadap yayasan-yayasan di Indonesia. Meskipun masih dalam kajian dan berupa hipotesa peneliti sampai saat ini, tetapi "Anod Foundation" ini akan menerapkan sistem-sistem dan revolusi yang dikaji saat ini."Anod Foundation" akan bekerja sama dengan Pemda Provinsi setempat untuk penerapan sistem ini. Kajian yang dilakukan yaitu membuat batasan bagi berdirinya yayasan. Dari data Pemda Provinsi setempat, maka perlu tidaknya berdirinya yayasan disesuaikan oleh data mereka. Pengumpulan data ini, Pemda Provinsi setempat juga bekerja sama dengan Pemda Kabupaten/kota. "Anod Foundation" memili kepanjangan (Anything For Dreams). Yayasan-yayasan yang berlingkup anak jalanan dan anak yatim/piatu akan diintegrasi menjadi satu yayasan yang efektif dan maksimal. [15]

\section{Revolusi Sumber Daya Manusia dan Mental}

Kriteria anak jalanan dari Departemen Sosial memaparkan bahwa anak jalanan adalah anakyang sebagian besarwaktunya dihabiskan untuk mencari nafkah atau berkeliaran di jalanan atau tempat-tempat umum lainnya, usia mereka berkisar dari 6 tahun sampain 18 tahun. Adapun waktu yang dihabiskan di jalan lebih dari 4 jam dalam satu hari. Pada dasarnya anak jalanan menghabiskan waktunya di jalan demi mencari nafkah, baik dengan kerelaan hati maupun dengan paksaan orang tuanya. Kriteria anak yatim/piatu berdasarkan sabda Rasulullah SAW yaitu: "Tidak lagi disebut yatim, anak yang sudah bermimpi (baligh)." (HR. Abu Daud dari Ali bin Abi Thalib). Anak yatim/ piatu adalah anak yang ditinggalkan oleh orang tuanya dalam usia yang belum baligh. Rata-rata yayasan memiliki visi misi yang sudah baik, namun jika pengintegrasian yayasan anak jalanan dan anak yatim/piatu dilakukan, maka perlu dilakukannya revolusi sumber daya manusia dan mental anak yang lebih 
luas dan mencakup keduanya. Revolusi sumber daya manusia dan mental ini dilakukan untuk bekal masa depan mereka. Setiap anak harus mempunyai orientasi terhadap masa depan. Seginer (2002) menyatakan bahwa orientasi masa depan adalah representasi mental tentang masa depan yang dibangun oleh individu pada titik-titik tertentu dalam kehidupan mereka dan mencerminkan pengaruh kontekstual pribadi dan sosial. [16]

Ginanjar (2004) , Orientasi masa depan adalah bagaimana seseorang merumuskan dan menyusun visi kedepan dengan membagi orientasi jangka pendek, menengah, dan jangka panjang. Dalam Islam dijelakan dalam (Q.S. Al Hasyr : 18) yang artinya:

"Hai orang-orang yang beriman, bertakwalah kepada Allah dan hendaklah setiap diri memperhatikan apa yang telah diperbuatnya untuk hari esok (akhirat), dan bertakwalah kepada Allah, sesungguhnya Allah Maha Mengetahui apa yang kamu kerjakan".

Hal pertama yaitu Revolusi Sumber Daya Manusia dan Mental dilandasi dengan persiapan bagi setiap orang untuk bekal masa depannya baik di dunia dan diakhirat. Program yang di lakukan oleh "Anod Foundation" ini yaitu :

1. Program revolusi sumber daya manusia dan mental, melalui penyediaan pendidikan formal, non formal dan informal sekaligus untuk anak jalanan dan anak yatim/piatu yang putus pendidikan.[17]

2. Program kesejahteraan dan peningkatan ekonomi mandiri untuk anak jalanan dan anak yatim/piatu.

3. Program penggalian minat bakat dan pengasahaan softskills sejak dini, dan pelatihan.

4. Program jangka panjang untuk keikutsertaan sosial dan penyaluran ketenagakerjaan yang berguna bagi masyarakat dan negara.

Secara garis besar dari programprogram tersebut, diharapkan bisa meningkatkan kualitas Sumber Daya Manusia dan Mental anak jalanan dan anak yatim/piatu.

\section{Revolusi Pola Pikir dan Mindset}

Pola pikir yang harus dirubah disini, yaitu dari sisi anak jalanan dan anak yatim/ piatu itu sendiri serta dari sisi masyarakat. Dari sisi anak jalanan dan anak yatim/ piatu, peran yayasan adalah memberikan pengertian dan melakukan pendekatan terhadap mereka. Setiap anak, baik anak jalanan atau anak yatim/piatu memiliki hak asasi manusia, janganlah mereka mempunyai pemikiran menggantungkan hidupnya hanya karena status sosial dan ekonomi mereka saja. Menjadikan mental mustahiq menjadi muzaki. Mereka harus sadar bahwa mereka juga memiliki hak yang sama, bebas untuk berkarya atau berinovasi, dan berguna bagi masyarakat dan negara.[18]

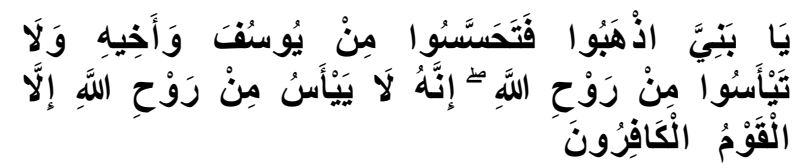

"Hai anak-anakku, pergilah kamu, maka carilah berita tentang Yusuf dan saudaranya dan jangan kamu berputus asa dari rahmat Allah. Sesungguhnya tiada berputus asa dari rahmat Allah, melainkan kaum yang kafir". (QS. Yusuf : 87)

Dari sisi masyarakat, masyarakat juga harus paham kalau mereka sebenarnya adalah anak-anak yang harus diperhatikan, mereka juga bukan anakanak dengan status sosial rendah saja, menyamaratakan hak bagi setiap anak tanpa memandang status sosial mereka itu penting dengan kepedulian kita, 
dan mereka bukanlah anak-anak yang patut disalahkan hanya dengan status sosial mereka, sebab kita lah yang harus mengerti sikon mereka.

Imam Al Banna pun berpesan:

"Di atas tonggak yang kokoh, bangunlah kebangkitan kalian, perbaiki jiwa kalian, fokuskan dawah kalian dan pimpinlah umat menuju kebaikan, niscaya Allah bersama kalian dan tidak akan menyia-nyiakan amal kalian." Dengan pola pikir ini, maka akan terbentuklah sebuah pemikiran dan mindset positif dan bernilai baik terhadap anak jalanan dan anak yatim/piatu.

Rasulullah SAW besabda: "Siapa yang tidak peduli dengan urusan kaum muslimin maka bukanlah golongan kaum muslimin." (HR. Muslim).

\section{KESIMPULAN}

Dari pemaparan dan penelitian ini dapat disimpulkan sebagai berikut: Merevolusi sistem yayasan di Indonesia yang terintegrasi, khususnya di lingkup yayasan anak jalanan dan yayasan anak yatim/piatu dengan dibenahinya peraturan perundang-undangan tentang pendirian yayasan, juga menjadi acuan bagi pendirian atau penggabungan yayasan-yayasan di semua lingkup pada umumnya nantinya. Merevolusi Sumber Daya Manusia (SDM) dan Mental anak jalanan dan anak yatim/piatu melalui yayasan yang lebih efektif dan maksimal untuk masa depan mereka. Merevolusi pola pikir dan mental dari segi anak jalanan dan anak yatim/piatu yang menggantungkan hidupnya dengan pasrah karena kondisi status sosial dan ekonominya. Juga dari segi masyarakat agar harus paham kalau mereka sebenarnya adalah anak-anak yang harus diperhatikan, menyamaratakan hak bagi setiap anak tanpa memandang status sosial mereka itu penting dengan kepedulian kita, sehingga terbentuklah mindset yang positif bagi mereka.

\section{DAFTAR PUSTAKA}

[1] S. Jurdi, "GERAKAN SOSIAL ISLAM: Kemunculan, Eskalasi, Pembentukan Blok Politik dan Tipologi Artikulasi Gerakan," J. Polit. Profetik, vol. 1, no. 1, 2013.

[2] N. Muthoifin, "KONTEKSTUALISASI MAKNA ZAKAT: STUDI KRITIS KOSEP SABILILLAH MENURUT MASDAR FARID MAS'UDI," in The 3rd University Research Colloquium 2016, 2016, pp. 185-191.

[3] Muthoifin, Nuha, and Mujiburohman, "Politik Otonomi Daerah Dalam Bingkai Islam Dan Keindonesiaan," in Prosiding The 3rd University Research Colloquium 2016, 2016, pp. 1-10, [Online]. Available: https://publikasiilmiah.ums.ac.id/ bitstream/handle/11617/6706/1.Mutholifin -Perspektif.pdf?sequence=1.

[4] Z. Mubarok, D. Hafidhuddin, H. Tanjung, and A. M. Tamam, “Konsep Pendidikan Wirausaha bagi Anak Panti Asuhan dan Pengaruhnya terhadap Kemandirian Anak," Ta'dibuna J. Pendidik. Islam, vol. 7, no. 2, p. 152, 2018, doi: 10.32832/tadibuna. v7i2.1359.

[5] I. W. Saputro, "Penanaman Pendidikan Karakter di Lembaga Pendidikan NonFormal (Studi Kasus di Homeschooling Group Khairu Ummah, Bantul)," AtTa'dib, vol. 12, no. 1, p. 19, 2017, doi: 10.21111/at-tadib.v12i1.882.

[6] Abdullah, “Konsep Pemikiran Didin Hafidhuddin," 2017.

[7] H. Ja'far, "Indonesian Islamic Education: Towards Science Development," 
Walisongo J. Penelit. Sos. Keagamaan, vol. 23, no. 2, p. 331, 2015, doi: 10.21580/ ws.23.2.309.

[8] S. P. Muthoifin, Budi Purnomo, "Standarisasi dan Optimalisasi Pariwisata Syariah Di Jawa Tengah," in APPPTMA KE-8 Medan 2018, 2018, pp. 1-7.

[9] Afandi, "Mewujudkan Pendidikan Multikultural Di Indonesia (Sebuah Kajian Pendidikan Multikultural Di Berbagai Negara)," Researchgate, no. October, pp. 1-9, 2018, doi: 10.13140/RG.2.2.36701.87527.

[10] D. Hafidhuddin, "ISLAM DAN PENANGGULANGAN KEMISKINAN Didin Hafidhuddin," J. Ekon. Islam Al-Infaq, vol. 3, no. 1, pp. 25-32, 2012.

[11] Muthoifin, "Konsep Guru Dan Murid Dalam Pandangan Ibn Jama ' Ah," in Prosiding Konferensi Nasional Ke- 4 Asosiasi Program Pascasarjana Perguruan Tinggi Muhammadiyah (APPPTM), 2016, pp. 128-134.

[12] imam Gunawan, Metode Penelitian KUALITATIF. 2016, pp. 1-27.

[13] J. Francoise, "Pesantren as the Source of Peace Education," Walisongo J. Penelit. Sos. Keagamaan, vol. 25, no. 1, p. 41, 2017, doi: 10.21580/ws.25.1.1161.

[14] Muthoifin, "Pembinaan Kerukunan Masyarakat Baru Pada Perumahan Baru Perum Griya Salaam Boyolali," in The 10th University Research Colloqium 2019 Sekolah Tinggi Ilmu Kesehatan Muhammadiyah Gombong, 2019, pp. 12-15.

[15] D. R. Dogan, "Discussion over Theological and Political Foundations of Caliphate in Islam," J. Islam. Stud. Cult., vol. 6, no. 2, pp. 1-8, 2018, doi: 10.15640/jisc.v6n2a1.

[16] S. Qutub, D. Hafidhuddin, and E. Mujahidin, "Metode Pembelajaran Kepemimpinan Rasulullah SAW Kepada Para Sahabat dalam Kitab Sunan Ibn Majah," Ta'dibuna J. Pendidik. Islam, vol. 5, no. 1, p. 25, 2016, doi: 10.32832/tadibuna. v5i1.582.

[17] Muthoifin, "Pemikiran Pendidikan Multikultural Ki Hadjar Dewantara," Intizar, vol. 21, no. 2, pp. 299-320, 2015, doi: 10.19109/intizar.v21i2.314.

[18] Muthoifin, "SISTEM PENDIDIKAN NASIONAL DAN PENDIDIKAN ISLAM : Studi Krisis Pemikiran Ki Hadjar Dewantara Perspektif Islam," Wahana Akad., vol. 53, no. 9, pp. 1689-1699, 2013, doi: 10.1017/CBO9781107415324.004. 